\title{
Effect of Nd Addition on the Microstructure and Martensitic Transformation of Ni-Ti Shape Memory Alloys
}

\author{
M. Dovchinvanchig, ${ }^{1,2}$ C. W. Zhao, ${ }^{1}$ S. L. Zhao, ${ }^{1}$ X. K. Meng, ${ }^{1}$ Y. J. Jin, ${ }^{1}$ and Y. M. Xing ${ }^{1}$ \\ ${ }^{1}$ College of Science, Inner Mongolia University of Technology, Hohhot 010051, China \\ ${ }^{2}$ Institute of Physics and Technology, Mongolian Academy of Sciences, 210351 Ulaanbaatar, Mongolia \\ Correspondence should be addressed to C. W. Zhao; cwzhao@aliyun.com
}

Received 19 February 2014; Revised 18 April 2014; Accepted 2 May 2014; Published 20 May 2014

Academic Editor: Shuichi Miyazaki

Copyright (c) 2014 M. Dovchinvanchig et al. This is an open access article distributed under the Creative Commons Attribution License, which permits unrestricted use, distribution, and reproduction in any medium, provided the original work is properly cited.

The effect of rare earth element $\mathrm{Nd}$ addition on the microstructure and martensitic transformation behavior of $\mathrm{Ni}_{50} \mathrm{Ti}_{50-x} \mathrm{Nd}_{x}$ $(x=0,1,3,7,20)$ shape memory alloy was investigated experimentally. The results showed that the microstructure of Ni-Ti-Nd ternary alloy consists of the NiNd phase and the NiTi matrix. One-step martensitic transformation was observed in all alloys. The martensitic transformation start temperature $M_{s}$ increased gradually with increasing $\mathrm{Nd}$ content for Ni-Ti-Nd alloys.

\section{Introduction}

$\mathrm{Ni}$-Ti based shape memory alloys (SMAs) have unique shape memory effects and super-elasticity behavior and have been used in various fields, particularly in engineering and medical applications [1]. Current research interest on SMAs mainly lies in controlling the martensitic transformation temperature and improving the shape memory effect for their applications. The effects of martensitic transformation, superelasticity, and shape memory have been widely studied by adding transitional elements to $\mathrm{Ni}$-Ti binary alloys. These elements include $\mathrm{Fe}$ [2], $\mathrm{Hf}$ [3], and $\mathrm{Pd}$ [4]. It is found that most alloying elements such as Fe lower martensitic transformation temperature, but there are only a few, such as $\mathrm{Hf}$ and $\mathrm{Pd}$, which increase martensitic transformation temperature [5].

Moreover, the microstructure and martensitic transformation temperature of the rare earth (RE) of Ce [6], Gd [7], Dy [8], and La [9] in addition to Ni-Ti binary alloys have also been studied using scanning electron microscopy (SEM), energy dispersive spectrometry (EDS), X-ray diffraction (XRD), and differential scanning calorimetry (DSC). The addition of these REs to Ni-Ti binary alloys was found to increase the martensitic transformation temperature and change the phase transformation sequence.
RE element $\mathrm{Nd}$ is also a widely used element, particularly in magnetic materials. However, only few studies have been conducted on $\mathrm{Nd}$ addition to shape memory alloy. The only study found in the literature is that on $\mathrm{Nd}$ addition to $\mathrm{Ni}$ Ti-Fe alloy, but the Nd fraction is less than 1 at.\% [10]. The effect of $\mathrm{Nd}$ addition to Ni-Ti binary alloy on microstructure and martensite transformation temperature remains unclear. In this paper, $\mathrm{Nd}$ content with atomic fractions of $1 \%, 3 \%$, $7 \%$, and $20 \%$ was added to Ni-Ti binary alloys, and the microstructure and martensitic transformation were studied experimentally.

\section{Material and Methods}

The $\mathrm{Ni}_{50} \mathrm{Ti}_{50-x} \mathrm{Nd}_{x}$ alloys were prepared by melting each $10 \mathrm{~g}$ of raw materials with different nominal compositions (99.9 mass\% sponge $\mathrm{Ti}, 99.7$ mass\% electrolytic $\mathrm{Ni}$, and 99.95 mass\% Nd) in a nonconsumable arc-melting furnace using a water-cooled copper crucible. The alloys are denoted by $\mathrm{Nd} 0, \mathrm{Nd} 1, \mathrm{Nd} 3, \mathrm{Nd} 7$, and $\mathrm{Nd} 20$ to refer to $\mathrm{Ni}_{50} \mathrm{Ti}_{50}$, $\mathrm{Ni}_{50} \mathrm{Ti}_{49} \mathrm{Nd}_{1}, \mathrm{Ni}_{50} \mathrm{Ti}_{47} \mathrm{Nd}_{3}, \mathrm{Ni}_{50} \mathrm{Ti}_{43} \mathrm{Nd}_{7}$, and $\mathrm{Ni}_{50} \mathrm{Ti}_{30} \mathrm{Nd}_{20}$ alloys, respectively. Arc-melting was repeated four times to ensure the uniformity of composition. The specimens are spark-cut from the ingots and solution-treated at $850^{\circ} \mathrm{C}$ for an hour in a quartz tube furnace. Subsequently the specimens 
TABLE 1: Lattice parameters of Ni-Ti-Nd alloys.

\begin{tabular}{|c|c|c|c|c|c|c|c|}
\hline Alloy & Phase & $a\left(\mathrm{~nm}^{3}\right)$ & $b\left(\mathrm{~nm}^{3}\right)$ & $c\left(\mathrm{~nm}^{3}\right)$ & $\beta\left(^{\circ}\right)$ & $V\left(\mathrm{~nm}^{3}\right)$ & Source \\
\hline $\mathrm{Nd} 0$ & $\mathrm{M}$ & 0.2898 & 0.4121 & 0.4619 & 97.86 & 0.05464 & \multirow{9}{*}{ This work } \\
\hline \multirow{2}{*}{$\mathrm{Nd} 1$} & M & 0.2904 & 0.4123 & 0.4920 & 98.11 & 0.05475 & \\
\hline & A & 0.3009 & & & & 0.02724 & \\
\hline \multirow{2}{*}{$\mathrm{Nd} 3$} & M & 0.2939 & 0.4124 & 0.4639 & 98.39 & 0.05562 & \\
\hline & A & 0.3017 & & & & 0.02747 & \\
\hline \multirow{2}{*}{$\mathrm{Nd} 7$} & M & 0.2940 & 0.4136 & 0.4650 & 99.25 & 0.05579 & \\
\hline & A & 0.3021 & & & & 0.02757 & \\
\hline \multirow{2}{*}{$\mathrm{Nd} 20$} & M & 0.2948 & 0.4170 & 0.4657 & 99.48 & 0.05645 & \\
\hline & A & 0.3026 & & & & 0.02771 & \\
\hline \multirow[t]{2}{*}{$\mathrm{NiTi}$} & M & 0.2898 & 0.4108 & 0.4646 & 97.78 & 0.05480 & $\begin{array}{c}\text { JCPDF card } \\
\text { number } \\
65-0145\end{array}$ \\
\hline & A & 0.3007 & & & & 0.02719 & $\begin{array}{c}\text { JCPDF card } \\
\text { number } \\
65-4572\end{array}$ \\
\hline $\mathrm{NiTi}_{2}$ & & 1.131 & & & & 1.4503 & $\begin{array}{c}\text { JCPDF card } \\
\text { number } \\
72-0442 \\
\end{array}$ \\
\hline NiNd & & 0.3803 & 1.046 & 0.4339 & & 0.17262 & $\begin{array}{l}\text { JCPDF card } \\
\text { number } \\
19-0818\end{array}$ \\
\hline
\end{tabular}

were quenched using water. Thereafter, the specimens are mechanically and lightly polished to obtain a plain surface.

The phase transformation temperatures of $\mathrm{Ni}_{50} \mathrm{Ti}_{50-x} \mathrm{Nd}_{x}$ alloys were determined by DSC using a TA Q2000 calorimeter. The temperature range of heating and cooling was from $-30^{\circ} \mathrm{C}$ to $140^{\circ} \mathrm{C}$, and the scanning rate of heating and cooling was $10^{\circ} \mathrm{C} / \mathrm{min}$. SEM observations were conducted using a FEI Quanta 650 FEG equipped with EDS analysis systems made by Oxford. An XRD experiment was conducted using a D/MAX-2500PC X-ray diffractometer. The transmission electron microscope (TEM) sample was prepared using the standard technique involving mechanical grinding followed by Ar+ ion milling. TEM experiment was conducted on a JEM-2010 TEM at $200 \mathrm{kV}$. Images were recorded on a Gatan $1 \mathrm{k} \times 1 \mathrm{k}$ slow scan CCD camera and processed using the Gatan DigitalMicrograph software.

\section{Results and Discussion}

3.1. Microstructure of $N i_{50} T_{50-x} N d_{x}$ Alloy. Figure 1(a) depicts the XRD curves of $\mathrm{Ni}_{50} \mathrm{Ti}_{50-x} \mathrm{Nd}_{x}(x=0,1,3,7,20)$ alloys at room temperature. The diffraction peaks are identified to be from NiTi B19' martensite phase, NiTi B2 austenite phase, $\mathrm{NiTi}_{2}$ phase, and NiNd alloy after comparing with JCPDF cards (numbers 65-0145, 65-4572, 72-0442, and 190818). The detailed crystal plane indices are marked in Figure 1(b) for $\mathrm{Nd} 0$ and Figure 1 (c) for $\mathrm{Nd} 3$, but the relative intensities of each XRD curve are quite different because of the differences in martensite phase fraction and austenite phase fraction. In this paper, the letter $\mathrm{M}$ denotes the NiTi B19' martensite phase and the letter A denotes the NiTi B2 austenite phase. This perspective will be confirmed in the following DSC analysis. Figure 1(d) depicts a comparison of $(111)_{M}$ diffraction peaks of $\mathrm{Ni}_{50} \mathrm{Ti}_{50-x} \mathrm{Nd}_{x}(x=0,1,3,7,20)$ alloys. The $(111)_{M}$ peak is observed to move toward the left for $\mathrm{Ni}_{50} \mathrm{Ti}_{50-x} \mathrm{Nd}_{x}(x=1,3,7,20)$ alloys; that is, the diffraction angle decreases with increasing $\mathrm{Nd}$ fraction, which indicates that the interplanar spacing of (111) of the martensite expands with $\mathrm{Nd}$ addition from 1 at.\% to 20 at.\%. The lattice parameters of alloys can be also calculated by peaks' position in XRD curves and shown in Table 1 . It is shown clearly that the cell volume $V$ expands for either martensite or austenite with $\mathrm{Nd}$ addition to $\mathrm{Ni}$-Ti binary alloy from 0 at.\% to 20 at.\%. The observation can also be confirmed in the following composition analysis.

3.2. Morphologies and Compositions of $N i_{50} T i_{50-x} N d_{x}$ Alloys. Figure 2 depicts the backscattering SEM images of $\mathrm{Ni}_{50} \mathrm{Ti}_{50-x} \mathrm{Nd}_{x}(x=0,1,3,7,20)$ alloys. For $\mathrm{Nd} 0$ alloy, there are two different morphologies, namely, black phase and matrix, which can be identified in the SEM image (Figure 2(a)). The black phase is in irregular shape and distributed randomly in the matrix. For Nd1, Nd3, and Nd7, two different morphologies, namely, white phase and matrix, can be identified in the SEM images (Figures 2(b)-2(d)). Some white particles that are nearly round-shape and up to $4 \mu \mathrm{m}, 6 \mu \mathrm{m}$ and $11 \mu \mathrm{m}$ in diameter, respectively, with white curving areas can be found to be distributed randomly in the matrix. When the $\mathrm{Nd}$ content is 20 at.\%, the white phase mainly takes on very irregular shape and becomes larger and interconnected, while some white particles that are nearly round-shaped and up to $14 \mu \mathrm{m}$ are also found to be distributed in the matrix in Figure 2(e). The size of the white particles evidently increases, whereas the white 


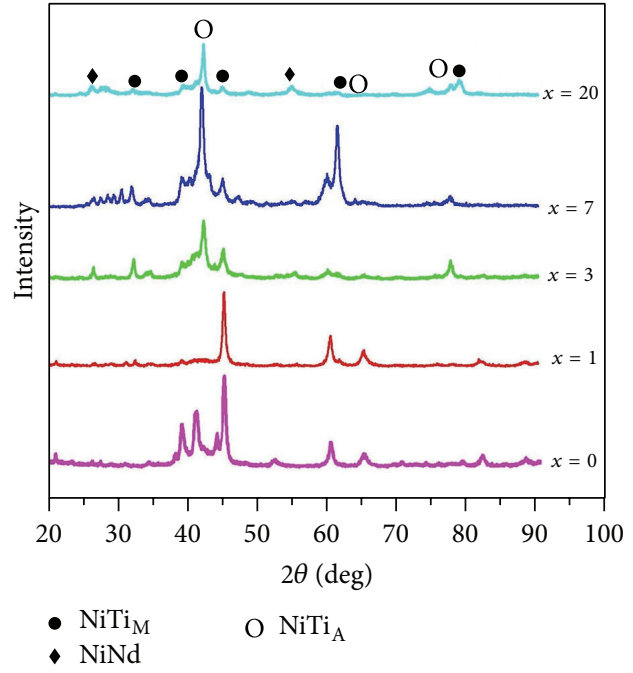

(a)

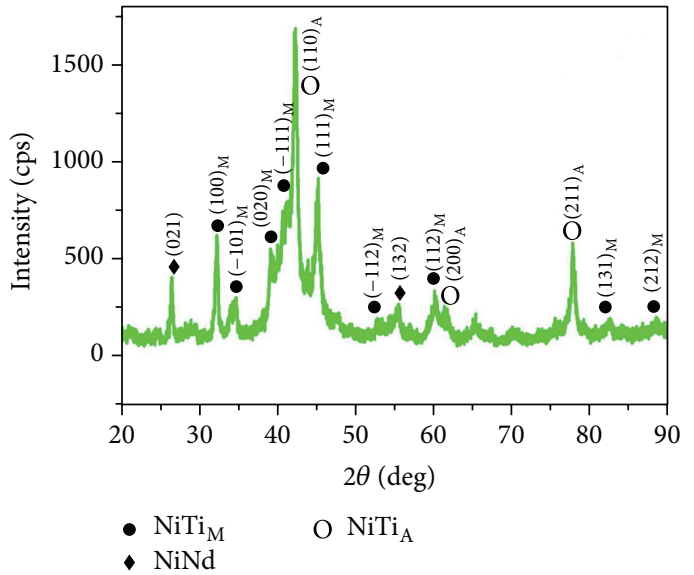

(c)

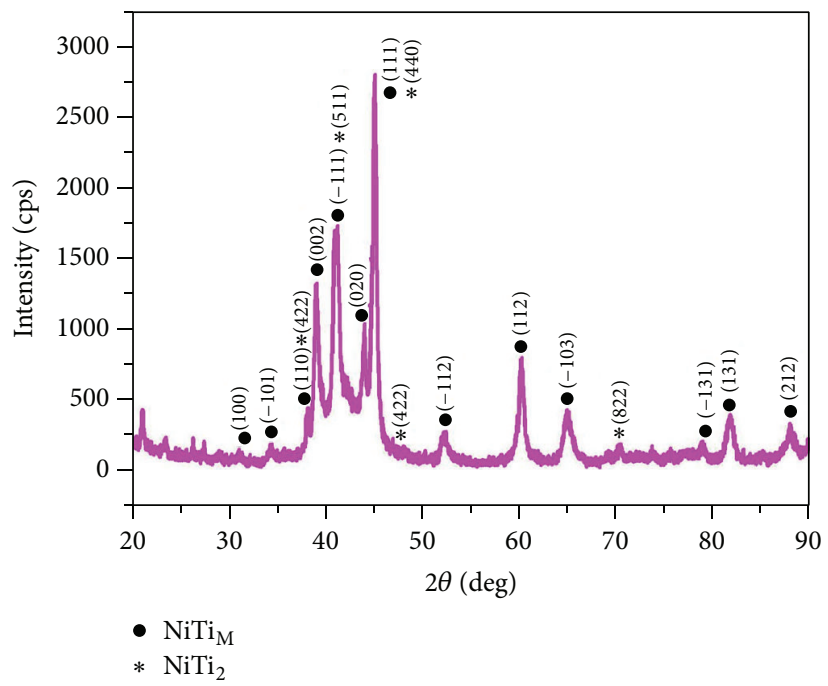

(b)

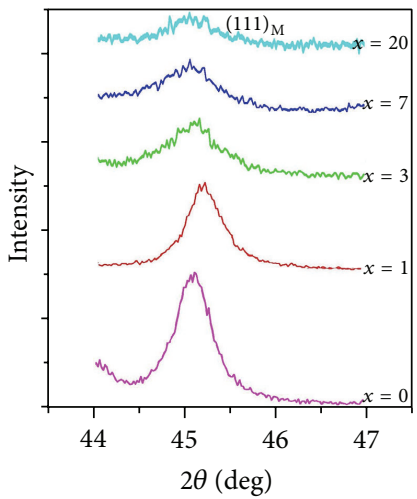

(d)

FIgURE 1: XRD curves of $\mathrm{Ni}_{50} \mathrm{Ti}_{50-x} \mathrm{Nd}_{x}$ alloys: (a) XRD curves of $\mathrm{Ni}_{50} \mathrm{Ti}_{50-x} \mathrm{Nd}_{x}$ alloys; (b) indexed diffraction peaks in Nd0; (c) indexed diffraction peaks in $\mathrm{Nd} 3$; (d) comparison of $(111)_{\mathrm{M}}$ diffraction peaks of $\mathrm{Ni}_{50} \mathrm{Ti}_{50-x} \mathrm{Nd}_{x}$ alloys.

phase overspreads steadily on the matrix with increasing $\mathrm{Nd}$ fraction.

To identify the boundaries between the white phase and the matrix, TEM observation was conducted for Nd1 alloy and the TEM bright field images of a small nearly roundshaped particle with a diameter of $1.7 \mu \mathrm{m}$ and a large nearly round-shaped particle with a diameter of $3.6 \mu \mathrm{m}$ are shown in Figure 3. The boundaries between these two particles and the matrix look very bright and can be identified clearly at such a very low magnification, which means that the boundaries are incoherent. Furthermore, $\mathrm{Xu}$ et al. proposed that the binding force of $\mathrm{RE}$ elements and $\mathrm{Ni}$ is much bigger than that of $\mathrm{Ni}$ and $\mathrm{Ti}$ [11]. So, NiNd phase is formed first and then NiTi phase crystallization occurs during the Ni-Ti-Nd alloys preparation. Thus NiNd phase and NiTi matrix have no orientation relationship [5].

To identify the phase structure, EDS analysis was conducted in SEM. The compositions of Ni-Ti-Nd alloys are shown in Table 2. The $\mathrm{Ti}$ : $\mathrm{Ni}$ ratio in the matrix of all $\mathrm{Ni}-\mathrm{Ti}$ $\mathrm{Nd}$ alloys is measured to be near 1 . Thus, the matrix can be concluded to be NiTi phase with a small amount of Nd solute. The $\mathrm{Ti}$ : Ni ratio in the black phase of $\mathrm{Nd} 0$ alloy is measured to be near $2: 1$. By XRD analysis, there is a $\mathrm{NiTi}_{2}$ phase in $\mathrm{Nd} 0$. Thus, the black phase can be concluded to be $\mathrm{NiTi}_{2}$ phase. According to the $773 \mathrm{~K}$ isothermal section of the ternary alloy phase diagram of the Ni-Ti-Nd, no intermetallic compounds can be found in the Ti-Nd binary system. However, Ni-Nd binary alloy phase diagram shows seven kinds of intermetallic compounds defined as $\mathrm{NdNi}_{5}, \mathrm{Nd}_{2} \mathrm{Ni}_{7}, \mathrm{NdNi}_{3}, \mathrm{NdNi}_{2}, \mathrm{NdNi}$, $\mathrm{Nd}_{7} \mathrm{Ni}_{13}$, and $\mathrm{Nd}_{3} \mathrm{Ni}$ [12]. The EDS results show that the $\mathrm{Ni}$ : $\mathrm{Nd}$ ratio in the white phase is near 1 and can be regarded as the NiNd intermetallic compound with a small amount of Ti solute. The amount and size of the NiNd phase increase with increasing $\mathrm{Nd}$ fraction (Figure 2).

Furthermore, $\mathrm{Nd}$ content has also been found in the matrix of $\mathrm{Nd} 3 \mathrm{Nd} 7$, and $\mathrm{Nd} 20$. The $\mathrm{Nd}$ atomic radius $(0.206 \mathrm{~nm})$ is known to be larger than $\mathrm{Ti}$ atomic radius 


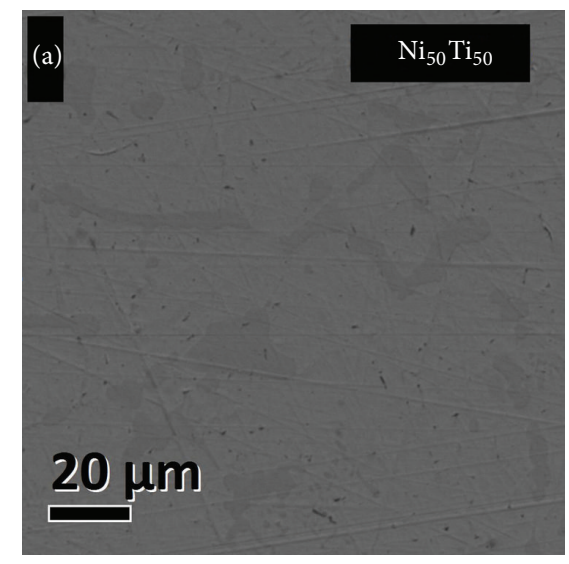

(a)

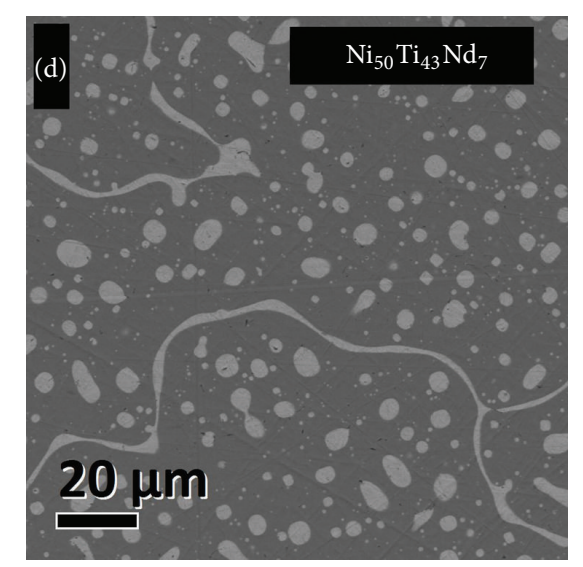

(d)

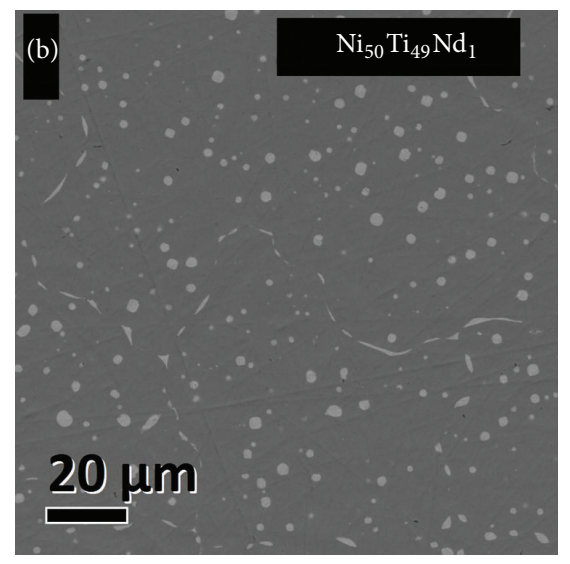

(b)

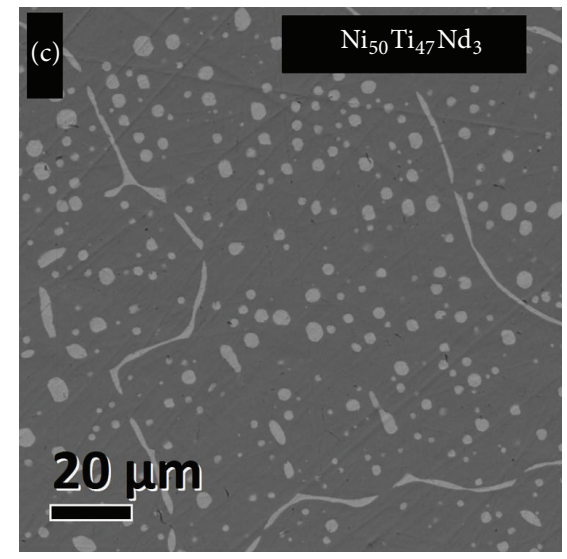

(c)

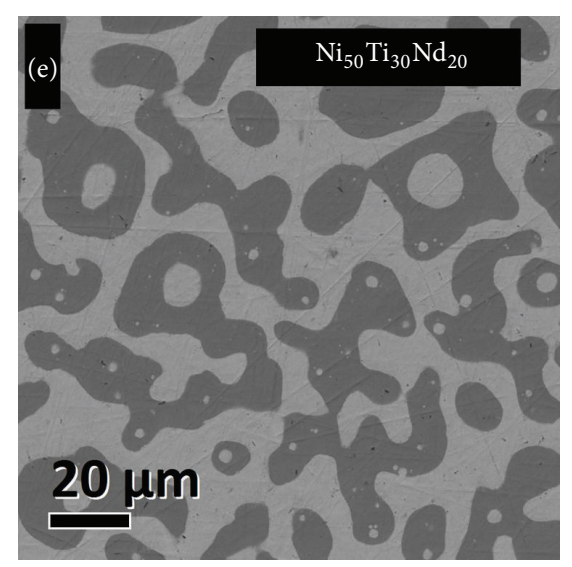

(e)

FIGURE 2: Back-scattering SEM images of $\mathrm{Ni}_{50} \mathrm{Ti}_{50-x} \mathrm{Nd}_{x}$ alloys: (a) $\mathrm{Ni}_{50} \mathrm{Ti}_{50}$; (b) $\mathrm{Ni}_{50} \mathrm{Ti}_{49} \mathrm{Nd}_{1} ;$ (c) $\mathrm{Ni}_{50} \mathrm{Ti}_{47} \mathrm{Nd}_{3} ;(\mathrm{d}) \mathrm{Ni}_{50} \mathrm{Ti}_{43} \mathrm{Nd}_{7} ;($ e) $\mathrm{Ni}_{50} \mathrm{Ti}_{30} \mathrm{Nd}_{20}$.

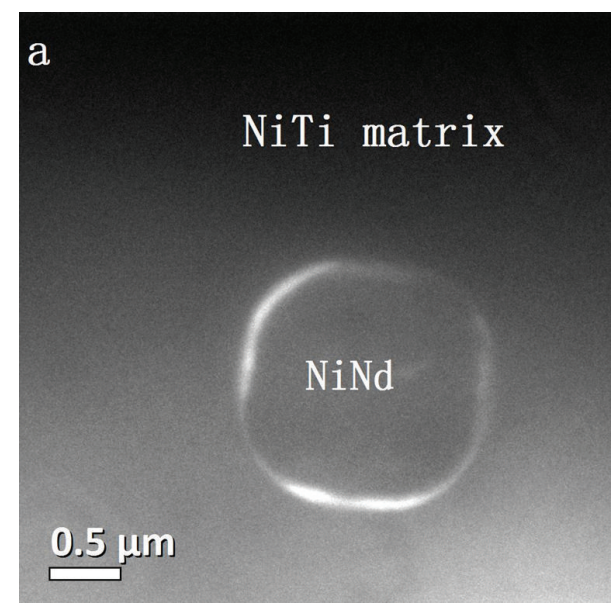

(a)

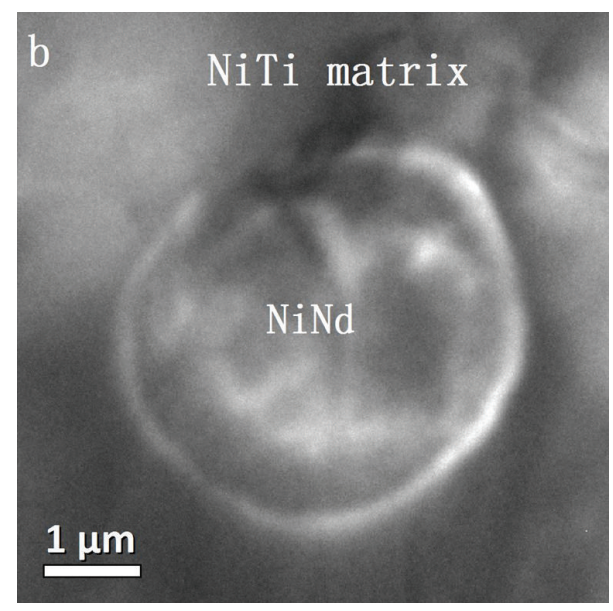

(b)

FIgURE 3: TEM bright field images of $\mathrm{Ni}_{50} \mathrm{Ti}_{49} \mathrm{Nd}_{1}$ alloy: (a) small particle; (b) large particle. 


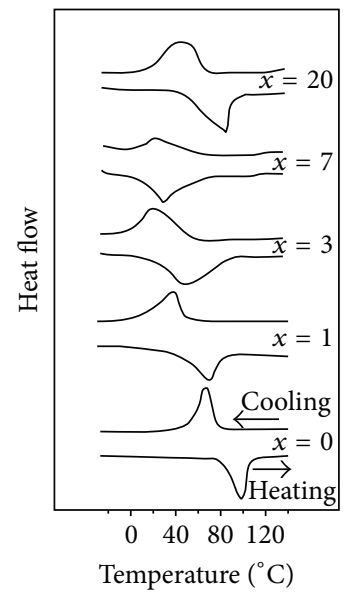

(a)

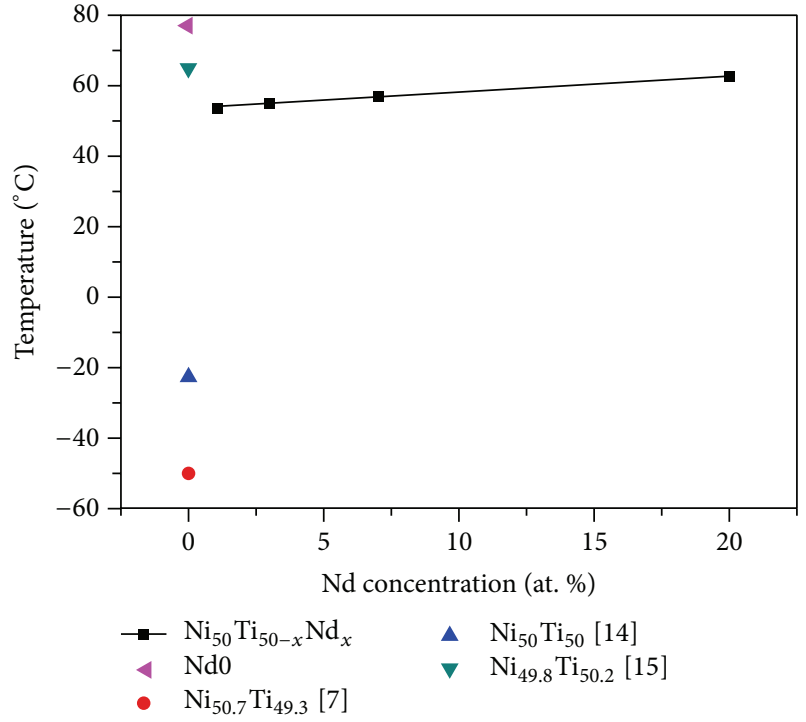

(b)

FIGURE 4: DSC curve and martensite transformation temperature of $\mathrm{Ni}_{50} \mathrm{Ti}_{50-x} \mathrm{Nd}_{x}$ alloys: (a) DSC curves; (b) $M_{s}$ curve.

$(0.176 \mathrm{~nm})$ by $17 \%$ and $\mathrm{Ni}$ atomic radius $(0.149 \mathrm{~nm})$ by $38 \%$ [13]. The Nd atom occupies the position of $\mathrm{Ni}$ or $\mathrm{Ti}$, consequentially resulting in an expansion of the NiTi matrix lattice [7], which is consistent with the previous XRD analysis.

3.3. Phase Transformation of $N i_{50} T_{50-x} N d_{x}$ Alloys. Figure 4(a) depicts the DSC curves of the $\mathrm{Ni}_{50} \mathrm{Ti}_{50-x} \mathrm{Nd}_{x}(x=$ $0,1,3,7,20)$ alloys. Each DSC curve of $\mathrm{Nd} 0, \mathrm{Nd} 1, \mathrm{Nd} 3, \mathrm{Nd} 7$, and $\mathrm{Nd} 20$ shows only one peak during the heating and cooling process, which indicates a one-step $\mathrm{B} 2 \leftrightarrow \mathrm{B} 19^{\prime}$ phase transformation. Figure 4(b) shows the effect of $\mathrm{Nd}$ concentration on martensitic transformation start temperature $M_{s}$. For $\mathrm{Nd} 0$ alloy, the $M_{s}$ is measured to be $77.44^{\circ} \mathrm{C}$. It is well known that quenched Ni-Ti binary alloys show one-step $\mathrm{B} 2 \leftrightarrow{\mathrm{B} 19^{\prime}}^{\prime}$ transformation and the transformation temperatures are strongly dependent on $\mathrm{Ni}$ concentration $[5,7] .0 .1$ at.\% increase in Ni concentration can lower the $M_{s}$ of Ni-Ti binary alloys by more than $10^{\circ} \mathrm{C}$. For example, Liu et al. measured the $M_{s}$ to be about $-50^{\circ} \mathrm{C}$ for $\mathrm{Ni}_{50.7} \mathrm{Ti}_{49.3}$ alloy after annealing at $900^{\circ} \mathrm{C}$ for $60 \mathrm{~min}$ [7]. Tabish et al. measured the $M_{s}$ to be $-22.12^{\circ} \mathrm{C}$ for $\mathrm{Ni}_{50} \mathrm{Ti}_{50}$ alloy after annealing at $1000^{\circ} \mathrm{C}$ for $120 \mathrm{~min}$ [14]. Wasilewski et al. measured the $M_{s}$ to be $65^{\circ} \mathrm{C}$ for $\mathrm{Ni}_{49.8} \mathrm{Ti}_{50.2}$ alloy [15]. In this work, the composition of the matrix in $\mathrm{Nd} 0$ is measured to be $\mathrm{Ni}_{49.36} \mathrm{Ti}_{50.64}$, which is Ti-rich. So, a high $M_{s}$ of Ti$\mathrm{Ni}$ binary alloy $\mathrm{Nd} 0$ is reasonable. Again, the martensite transformations finish temperature $M_{f}$ in $\mathrm{Nd} 0$ alloy is higher than room temperature of $20^{\circ} \mathrm{C}$. Thus, the martensite transformations have finished at room temperature and the $\mathrm{Nd} 0$ alloy should be in total martensite phase, which is in agreement with the XRD results.

Meanwhile, as shown in Figure 4, the $M_{s}$ increases with increasing $\mathrm{Nd}$ fraction from 1 at.\% to 20 at. $\%$. And all $M_{f}$ in four DSC curves of $\mathrm{Nd}$ addition alloys are lower than room temperature. Thus, martensite transformation cannot
TABLE 2: Compositions of Ni-Ti-Nd alloys.

\begin{tabular}{lcccc}
\hline & & $\mathrm{Ti}($ at.\%) & $\mathrm{Ni}$ (at.\%) & $\mathrm{Nd}($ at.\%) \\
\hline \multirow{2}{*}{ Nd0 } & Matrix & 50.64 & 49.36 & - \\
& Black phase & 66.99 & 33.01 & - \\
Nd1 & Matrix & 50.61 & 49.39 & 0 \\
& White phase & 5.55 & 49.67 & 44.78 \\
Nd3 & Matrix & 49.24 & 50.21 & 0.55 \\
& White phase & 2.97 & 49.84 & 47.19 \\
Nd7 & Matrix & 49.99 & 48.95 & 1.06 \\
& White phase & 4.31 & 47.72 & 47.97 \\
\multirow{2}{*}{ Nd20 } & Matrix & 49.27 & 48.99 & 1.74 \\
& White phase & 1.68 & 49.78 & 48.54 \\
\hline
\end{tabular}

finish fully at room temperature, which indicates that both the austenite phase and the martensite phase exist in the $\mathrm{Ni}$ Ti-Nd alloy. For Ndl alloy, the $M_{f}$ is higher than the others, after which the martensite transformation has nearly finished. Thus, a higher martensite fraction than austenite fraction is present. Consequently, the XRD curve of Ndl shows that the intensities of the martensite diffraction peaks are significantly higher than those of austenite in Figure 1(a). With increasing $\mathrm{Nd}$ fraction, the $M_{f}$, the martensite fraction in the alloy, and the relative XRD intensities of the martensite diffraction peaks also decreased.

\section{Conclusions}

In summary, the effect of RE element $\mathrm{Nd}$ addition on the microstructure and martensitic transformation behavior was investigated by XRD, SEM, TEM, and DSC. The microstructure of the $\mathrm{Ni}_{50} \mathrm{Ti}_{50-x} \mathrm{Nd}_{x}$ alloys consists of NiNd alloy with a small amount of Ti solute and NiTi matrix with a small 
amount of Nd solute. The lattice of NiTi matrix is expanded by Nd addition. The Ni-Ti-Nd alloy has a one-step martensitic transformation. Increasing the $\mathrm{Nd}$ fraction, the martensitic transformation start temperature $M_{s}$ increases gradually.

\section{Conflict of Interests}

The authors declare that there is no conflict of interests regarding the publication of this paper.

\section{Acknowledgments}

This work was supported by the National Natural Science Foundation of China (Grant no. 51261017), the Program for New Century Excellent Talents in University (Grant no. NCET-10-0909), and the Specialized Research Fund for the Doctoral Program of Higher Education (Grant no. 20101514110002).

\section{References}

[1] K. Otsuka and X. Ren, "Recent developments in the research of shape memory alloys," Intermetallics, vol. 7, no. 5, pp. 511-528, 1999.

[2] J. Frenzel, J. Pfetzing, K. Neuking, and G. Eggeler, "On the influence of thermomechanical treatments on the microstructure and phase transformation behavior of $\mathrm{Ni}-\mathrm{Ti}$-Fe shape memory alloys," Materials Science and Engineering A, vol. 482-484, no. 1-2, pp. 635-638, 2008.

[3] X. L. Meng, W. Cai, Y. D. Fu, Q. F. Li, J. X. Zhang, and L. C. Zhao, "Shape-memory behaviors in an aged Ni-rich TiNiHf high temperature shape-memory alloy," Intermetallics, vol. 16, no. 5, pp. 698-705, 2008.

[4] Y. Liu, M. Kohl, K. Okutsu, and S. Miyazaki, "A TiNiPd thin film microvalve for high temperature applications," Materials Science and Engineering A, vol. 378, no. 1-2, pp. 205-209, 2004.

[5] K. Otsuka and X. Ren, "Physical metallurgy of Ti-Ni-based shape memory alloys," Progress in Materials Science, vol. 50, no. 5, pp. 511-678, 2005.

[6] W. Cai, A. L. Liu, J. H. Sui, and L. C. Zhao, "Effects of cerium addition on martensitic transformation and microstructure of $\mathrm{Ti}_{49.3} \mathrm{Ni}_{50.7}$ alloy," Materials Transactions, vol. 47, no. 3, pp. 716719, 2006.

[7] A. L. Liu, W. Cai, Z. Y. Gao, and L. C. Zhao, “The microstructure and martensitic transformation of $\left(\mathrm{Ti}_{49.3} \mathrm{Ni}_{50.7}\right)_{1-x} \mathrm{Gd}_{x}$ shape memory alloys," Materials Science and Engineering A, vol. 438440, pp. 634-638, 2006.

[8] A. L. Liu, Z. Y. Gao, L. Gao, W. Cai, and Y. Wu, "Effect of Dy addition on the microstructure and martensitic transformation of a Ni-rich TiNi shape memory alloy," Journal of Alloys and Compounds, vol. 437, no. 1-2, pp. 339-343, 2007.

[9] J. W. Xu, A. L. Liu, B. Y. Qian, and W. Cai, "Investigation on microstructure and phase transformation of $\mathrm{La}$ added $\mathrm{TiNi}$ shape memory alloy," Advanced Materials Research, vol. 557559, pp. 1041-1044, 2012.

[10] J. G. Wang and F. S. Liu, "Phase transformation and microstructure of $\mathrm{Ti}_{50} \mathrm{Ni}_{48-x} \mathrm{Fe}_{2} \mathrm{Nd}_{x}$ shape memory alloys," Chinese Journal of Aeronautics, vol. 22, no. 3, pp. 334-338, 2009.

[11] J.-W. Xu, A.-L. Liu, and W. Cai, "Crystal structure and formation mechanism of rare earth rich phases in Ti-Ni-Ce alloys," Journal of Functional Materials, vol. 39, no. 4, pp. 600-602, 2008 (Chinese).

[12] J. Q. Liu, Y. H. Zhuang, and Y. Q. Hu, “The $773 \mathrm{~K}$ isothermal section of the ternary phase diagram of the Nd-Ni-Ti," Journal of Alloys and Compounds, vol. 368, no. 1-2, pp. 180-181, 2004.

[13] E. Clementi, D. L. Raimondi, and W. P. Reinhardt, "Atomic screening constants from SCF functions. II. Atoms with 37 to 86 electrons," The Journal of Chemical Physics, vol. 47, no. 4, pp. 1300-1307, 1967.

[14] T. A. Tabish, S. Atiq, M. Ali, A. N. Ch, Z. U. Reham, and T. Z. Butt, "Development and characterization of $\mathrm{Ni}_{50} \mathrm{Ti}_{50}$ shape memory alloy used for biomedical applications," International Journal of Chemical, Materials Science and Engineering, vol. 7, no. 12, pp. 92-93, 2013.

[15] R. J. Wasilewski, S. R. Butler, and J. E. Hanlon, “On the martensitic transformation in TiNi," Metallurgical Transactions, vol. 1, no. 1, pp. 104-110, 1967. 

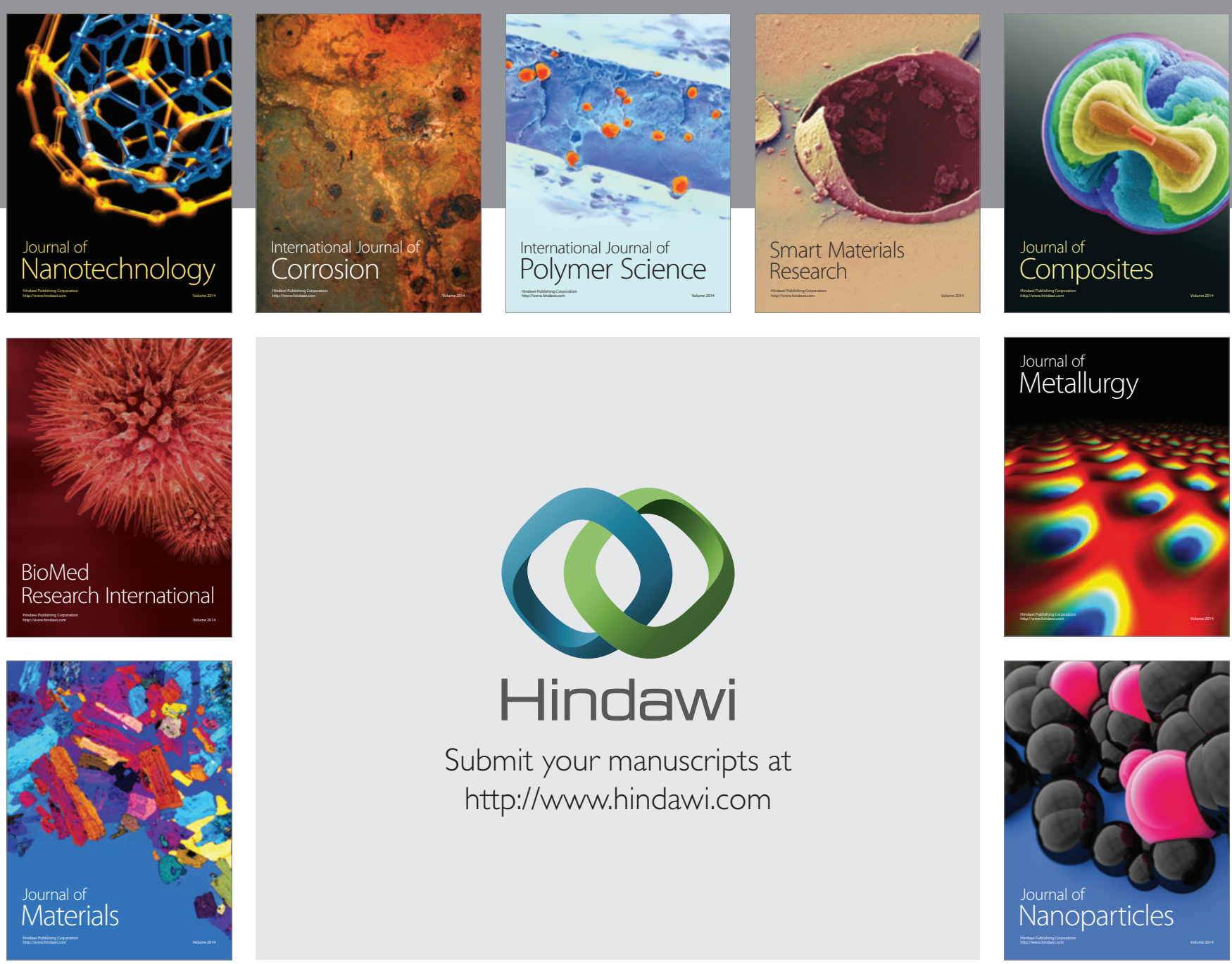

Submit your manuscripts at http://www.hindawi.com
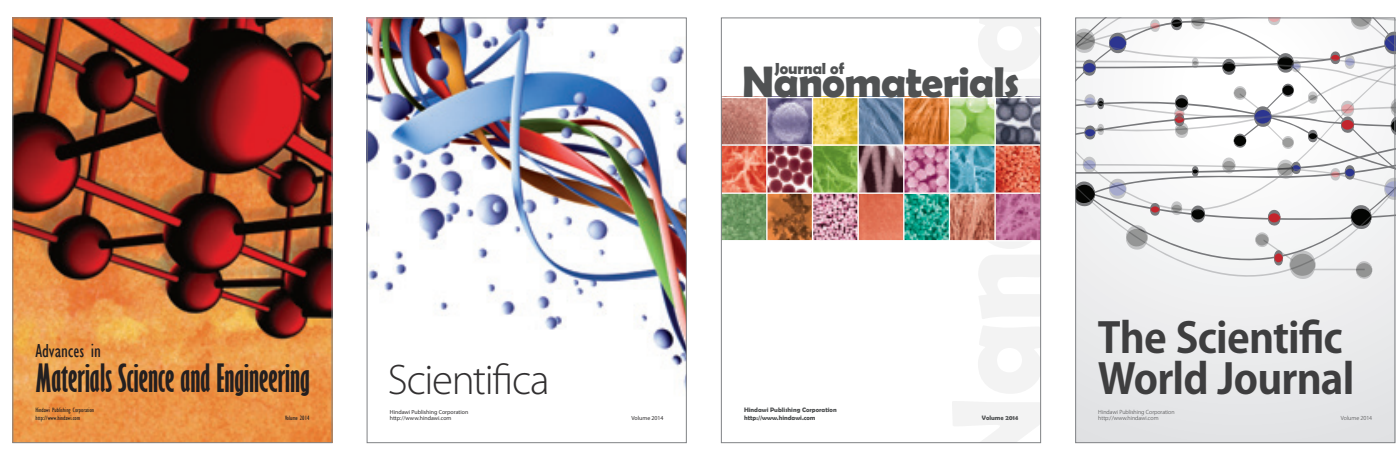

\section{The Scientific World Journal}
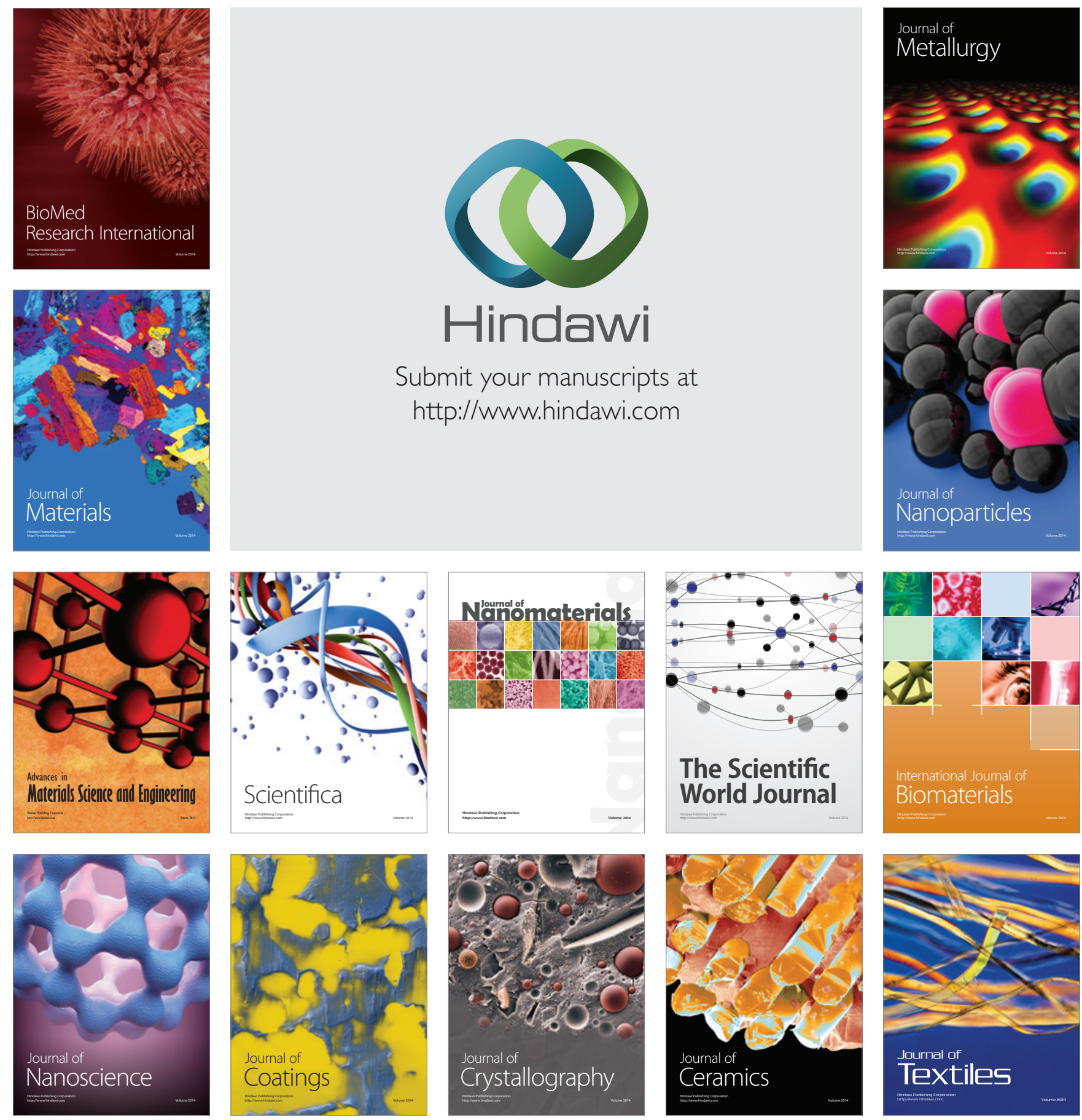